\title{
Influence of the geometrical researches of surfaces of revolution and translation surfaces on design of unique structures
}

\author{
Gérard L. Gbaguidi Aisse \\ University of Abomey-Calavi, 02 BP 244 Cotonou, Republic of Benin \\ gbaguidi.gerard@yahoo.fr
}

Article history:

Received: April 12, 2019

Revised: July 14, 2019

Accepted: July 22, 2019

\section{Abstract}

Aims of research. The use, design and analysis of architectural and building structures in the form of smooth and composite surfaces have become relevant and in demand lately, which determined the purpose of this article - to analyze the use of analytical surfaces given vector, parametric or explicit equations in real structures. Methods. The relationship between studies on the geometry of surfaces of revolution and transport and the creation of new forms of thin-walled structures and buildings is determined. An example of a real structure is given on each surface. The article does not consider composite, multifaceted, fractal surfaces, as well as surfaces that are not defined analytically. Results. It turned out that only a small number of considered surfaces of these two classes have found application in the world. At the end of the article, a bibliography is presented, which sets out the mathematical side of the design of analytical surfaces, their computer modeling, more detailed information about real structures in the form of the surfaces under consideration.

Keywords: surface of revolution; translation surface; architectural compositions; surface geometry; forming surfaces; surface classification; thin-walled dome

\section{Introduction}

Nowadays there are known more than 54 analytical surfaces of revolution, 17 surfaces of right translation, and several surfaces of oblique translation set by the explicit, implicit, or parametrical equations that are listed in an encyclopedia [1] and their graphical pictures are given in a book [2]. In some works, for example in [2-5], attempts to find out the most popular analytical surfaces among architects and builders, which were used for design of public, residential, and industrial buildings, were made. It was established that the most wide-spread forms of large-span shell structures have the middle surfaces in the form of surfaces of revo-

Gérard Léopold Gbaguidi Aisse, Professor of Department of Civil Engineering; Director, Verechaguine A.K. Graduate School of Civil Engineering, Director of Laboratory of Materials and Structures (LAMS).

(c) Gbaguidi Aisse G.L., 2019 (c) () International License https://creativecommons.org/licenses/by/4.0/ lution or surfaces of right translation. Examine the known thin-walled shell erections having the form of these surfaces of two classes and realized in practice. Every analytical surface would be illustrated with one erection outlined on the corresponding surface. The additional materials and sources connected with the considered subject will be given in the references.

\section{Surfaces of revolution}

The class of surfaces of rotation is the following class of surfaces from where engineers and architects take analogs of forms of their erections, structures, and products in the most cases. Everyone can create a huge number of surfaces of rotation choosing this or that flat generatrix curve and rotating it around a rotation axis. But only surfaces attracted attention of architects will be given here and these surfaces must be embodied in real structures. From 54 surfaces of revolution, presented in the encyclopedia [1], only spheres and one-sheet hyperboloids, ellipsoids, and paraboloids of revolution, 
drop-shaped and pseudospherical surfaces, catenoids and barrel-shaped surfaces found application in architecture and building. Their geometry is well investigated but in spite of it, researches try to find the optimal form of shell of revolution under diverse loading. 24 criterion of optimality are known [6].

An explicit equation of a surface of revolution can be presented in the following form:

$$
z=f(r)=f\left(\sqrt{x^{2}+y^{2}}\right)
$$

where $r=\sqrt{x^{2}+y^{2}}$ is the distance a point of the surface from the axis of rotation.

Right circular cylindrical and conical surfaces [7] are examples of surfaces generated by a straight line. Hyperboloids of one sheet are also surfaces of revolution [8]. It is better to attribute these three surfaces to a class of ruled surfaces.

Parametrical equations of arbitrary surface of revolution are

$$
r=r(r, \beta)=r \cos \beta i+r \sin \beta j+f(r) k .
$$

Here, an equation of a meridian is taken in the form $r=r(\alpha)$ where $\alpha$ is the angle of the normal to the surface passing through a given point with the axis of rotation. If an equation of a meridian is given in the form $r=r(z)$ then an equation of a surface of revolution can be written with the help of equations:

$$
x=r \sin \beta, y=r \cos \beta, z=z
$$

where $\beta$ is the angle of rotation of the plane of the meridian.

So, one can use a system of basic equations for stress-strain analysis in principal curvilinear coordinates [9]. A system of curvilinear coordinates in principal curvature lines coinciding with meridians and parallels is used in all researches devoted to geometrical modelling of surfaces of revolution and to strength analysis of shells of revolution.

\subsection{Sphere}

This surface is used in four types of structures: small architecture (Figure 1,a), structures in the form of a full sphere (Figure 1,b), 3) spherical domes (Figure 1,c), and structures from fragments of a spherical surface.

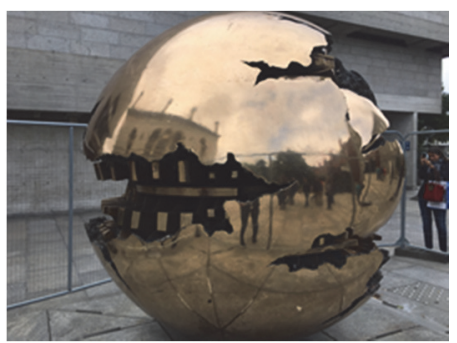

$a$

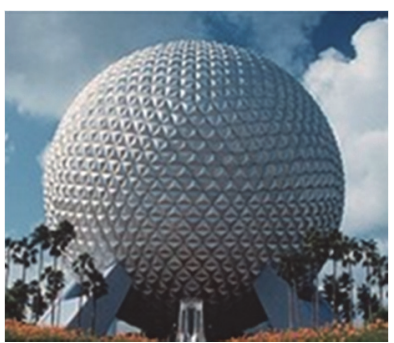

$b$

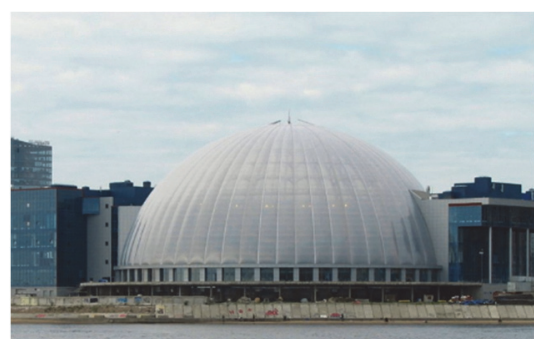

$c$

Figure 1. The application of spherical surfaces

$a$ - torn sphere, Dublin, Ireland; $b$ - the geodesic sphere "Spaceship Earth", the AT \& T Pavilion at Epcot in Disney World, Florida; $c$ - the world's largest wooden dome with a $92 \mathrm{~m}$ diameter, TRC "Piterland", Saint Petersburg

The new Opera House in Sydney (Australia) is one of Australia's most famous landmarks. The final version of the building contains 4 main shells, 4 side shells, and 2 auxiliary shells [10]. The surface of the half of each shell is a fragment of a sphere. The building covers an area of 2.2 hectares; the sails reach a height of $67 \mathrm{~m}$ and are faced with Swedish tiles, shiny in the sun. By the way, one of the reasons for replacing the shape of the elliptic paraboloid with a spherical one was the danger of rebounding of the facing plates from the base due to the difference in temperature deformations.

\subsection{Pseudosphere}

In the scientific-and-technical literature, examples of using of surface of a pseudosphere in the building industry were not found. Only Kenneth Brecher [11] pre- sented examples of pseudospheres realized in nature: a gypsum model of pseudosphere made by V.M. Schilling at the end of the XIX century; a large plywood model of pseudosphere "Mathematica" exhibited at the Museum of Science in Boston created by Charles and Ray Eames; a stainless steel sculpture "Cloud Gate" in Chicago's Millennium Park (Anish Kapoor, 2008); the model "Surface of revolution of constant negative curvature" (author is H. Sugimoto, 2004); the aluminum and glass sculpture by the same author "Conceptual Form 009" (2006); the metal wire figure "Funicular Polygon of Revolution - Pseudosphere" (Robert Le Ricolais, 1894-1977) (Figure 2). All these mathematical models serve educational purposes. In other cases, the authors were limited only to the wishes or suggestions for the application of these shells of rotation [12]. 


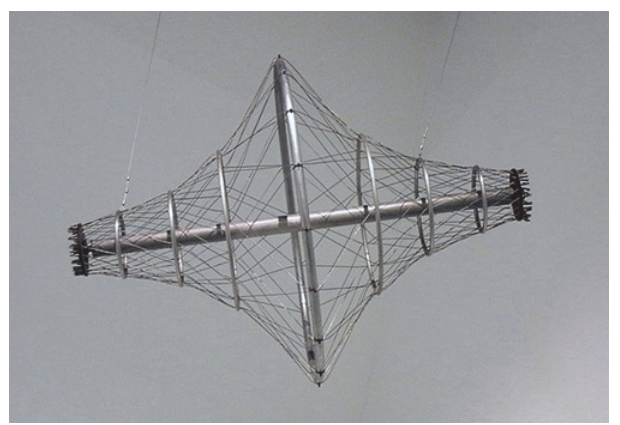

Figure 2. Metal wire shape "Funicular Polygon of Revolution - Pseudosphere", Robert Le Ricolais

\subsection{Paraboloid of revolution}

This surface has attracted the attention of ancient builders, for example, the parabolic dome of the Cathedral of St. Peter in Rome marked the beginning of a series of similar structures. It is believed that dome appeared in the East and had, above all, a utilitarian purpose. In the absence of wood, roofs for dwellings were made from clay and bricks. But gradually, thanks to its exceptional aesthetic and technical qualities, the dome acquired an independent semantic content as an architectural form. Intensive experimental and theoretical studies of parabolic shells of revolution, conducted recently, show that they are in demand as in practice so in science too. A very large number of examples of real structures in the form of paraboloid of revolution is given in a paper [13].

\subsection{Ellipsoid of revolution}

Buildings and structures in the form of ellipsoids of revolution can have not only architectural expressiveness but also some advantages in the distribution of internal force factors. In mechanical engineering, mainly, thin-walled shells in the form of ellipsoids of revolution are used for the bottoms and head parts of tanks and vessels for various purposes. However, there are many examples of the using of ellipsoids of revolution in the building industry. In details, this question is taken up in works $[2 ; 5]$.

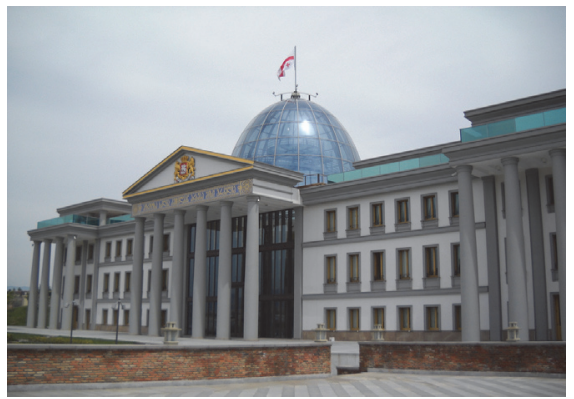

Figure 3. Palace of President of Georgia
The Church in Düsseldorf, architect P. Schneider, can be taken as the most vivid illustration of the functionality and architectural expressiveness of this form. One can point out the glass dome of Palace of President of Georgia in Tbilisi (Figure 3). Its form is very similar to an ellipsoid of revolution. The palace has been built from 2004 till 2009. The author of the project is G. Batiashvili.

\subsection{Catenoid}

The only minimal surface of revolution is catenoid and it was not used widely in building and machine-building else. The innovative project of a threestory pavilion with hollow columns in the form of a catenoid was presented by B. Janett. This form is chosen to ensure a smooth transition from the walls to the ceiling [14].

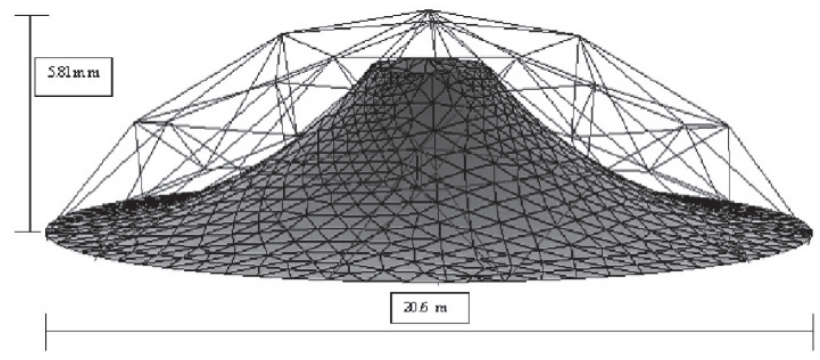

Figure 4. The design model of the pavilion coverage in the park of the Queretaro City, Mexico

A pre-stressed tubular rod structure in the form of a sphere supporting a film coating from polyester in the form of a catenoid with the help of steel cables was installed in the Alfalfares Park of Queretaro City, Mexico (Figure 4). The choice of form was dictated by the requirement of a minimum weight of the structure [15]. The system of catenoid shells from monolithic reinforced concrete of a $40 \mathrm{~cm}$ thick forms the structure of the National Theater of Taiwan (National Taichung Theater). It is also known as Taichung Metropolitan Opera House and located in Taichung City. The architectural project was completed by Toyo Ito and architectural group "Da-Ju Architects".

Apparently, the pavilion in the city of Queretaro (Mexico) and the catenoids of the National Theatre of Taiwan are the first examples of real application of catenoids in architecture.

\subsection{The barrel-shaped surface}

Very often this name of the surface is used by architects to describe a group of surfaces of rotation of an arbitrary flat curve, facing its vertex in the opposite direction from the axis of rotation. However, the ana- 
lytical surface with the same name does not exist, because it is necessary its broader interpretation. For example, a barrel-shaped surface of revolution with a directrix circle exists. This surface was taken as a basis for the shape of a residential building in Moscow (Figure 5.) Barrel-shaped surfaces are sometimes called egg-shaped surfaces. Unfortunately, the authors do not point out the equations of the selected surfaces, but only give the overall dimensions.

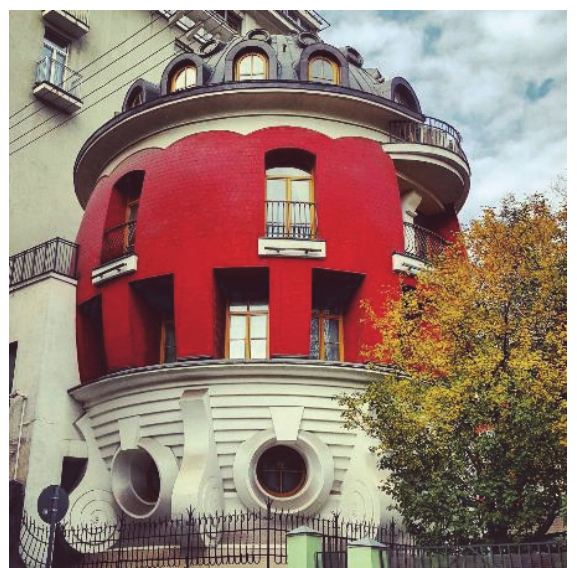

Figure 5. The House-Egg, Mashkova St., Moscow, Russia

\subsection{Drop-shaped surfaces}

This group of surfaces includes the surfaces of revolution resembling in form a drop of liquid lying on a horizontal plane. A thin-walled metal shell in the form of this surface is an equal-strength shell. The first tests of drop-shaped tanks were conducted in the USA in 1936. In 1944, the Gidrospetsneft Institute for the first time in the practice of the Soviet Union has developed a project of the drop-shaped tank with a volume of $2000 \mathrm{~m}^{3}$. S.I. Verevkin and G.M. Chichko are the authors of the project. According to this project in 1947 in Grozny, the first dropshaped tank was built. In the 1950s, the designers of the USA and Canada worked out drop-shaped shells as applied to water tanks for water towers. The shape of the drop was the basis of the project of the building of the main test stand of the All-Union Electrotechnical Institute in Istra, Moscow region. The structure had a $234 \mathrm{~m}$ diameter and a $112 \mathrm{~m}$ height. In 1984, the building collapsed immediately after the erection.

The unusual giant complex of the Folk Theater in the form of a drop which had become a new symbol of China was designed by the famous French architect Paul Andre. According to the sum of seats, the theatre of Beijing is already recognized as the largest cultural complex on Earth. The length of the theater building reaches $212 \mathrm{~m}$, its width is $143 \mathrm{~m}$, and the height is $46 \mathrm{~m}$.

\subsection{Bullet nose}

The upper part of London skyscraper "30 St Mary Axe" till the $17^{\text {th }}$ floor (Foster and Partners, Emporis Skyscraper Award in 2003), Glass Pavilion at the exhibition in Cologne (1914) and some other erections are rather like bullet nose in shape. Bullet nose in shape is very like external surface of bullet (Figure 6). This surface is formed by rotation of a curve

$$
x= \pm a z / \sqrt{b^{2}+z^{2}}
$$

around the $z$ axis of rotation (Figure 7).

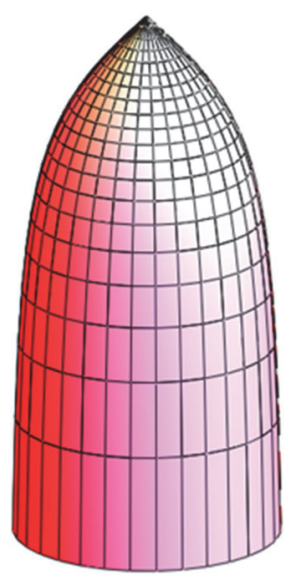

Figure 6. Bullet nose
Figure 7. The meridian of bullet nose

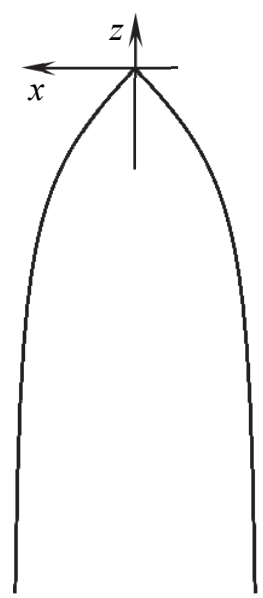

\section{Surfaces of translation}

These are very functional surfaces and therefore architects and civil engineers like them. They are often used as coverings of markets, shopping centers and sports grounds. Translation surfaces are surfaces formed by parallel transfer of a curve of some direction along another curve that is a directrix curve.

A surface of translation is a surface formed by parallel translation of a curve of some direction that is a generatrix curve along another curve that is a directrix curve. So, a point $M_{0}$ of the generatrix curve slides along the directrix curve.

\subsection{Surfaces of right translation}

Surfaces of right translation can be defined by an explicit equation:

$$
z=z(x, y)=z_{1}(x)+z_{2}(y)
$$

where $z=z_{1}(x)$ is the equation of a plane generatrix curve; $z=z_{2}(y)$ is the equation of a plane directrix curve. Directrix and generatrix curves of a surface can be arbitrary curves but usually they are taken of the same type.

These surfaces are typically used as shell models on a rectangular or square plan (Figure $8, a$ ). 


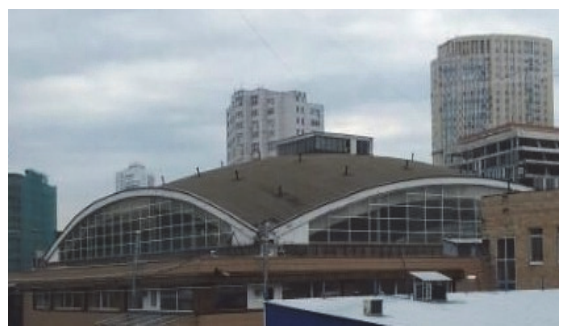

$a$

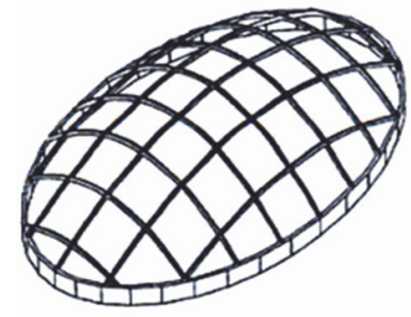

$b$

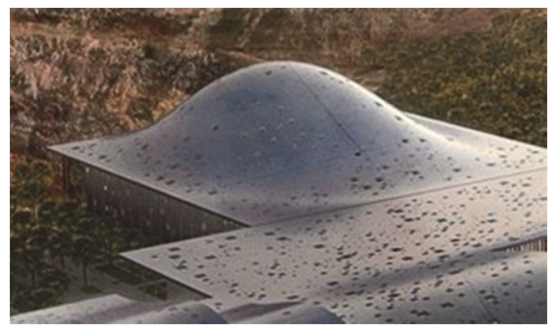

C

Figure 8. The application of translation surfaces:

$a$-Cheryomushkinsky market (circular translation surface), Moscow; $b$ - the layout of the parabolic arches of the gym, Hungary; $c$ - a fragment of the covering of Cultural Centre in Muscat, Oman, designed by Architecture-Studio architects (Paris)

Source: https://www.e-architect.co.uk/oman/cultural-centre-muscat

\subsection{Surfaces of oblique translation}

This surface is formed by parallel translation of a plane curve and two of its symmetrical points touch the plane contour continuously. These surfaces can be given by an explicit equation

$$
z=g(u-v)+h(u+v),
$$

where $z=g(u-v)$ is an equation of a plane generatrix curve; $z=h(u+v)$ is an equation of a plane directrix curve.

Theoretically, such surface can be formed on a contour of an arbitrary outline but the surfaces created on a contour with symmetry, for example, circumferences, ellipses, squares, ovals, rectangles, are of the greatest interest.

For example, in Hungary, a sports hall was built on an elliptical plan with $93 \times 61 \mathrm{~m}$ dimensions in axes and a height of $10.5 \mathrm{~m}$. Functional and constructive reasons required the erection of the building on an elliptical plan. The system of parabolic steel tubular arches located along the elliptic paraboloid translation networks with a step of $6 \mathrm{~m}$ in both directions was chosen as the supporting structure of the coating (Figure 8,b).

\subsection{Velaroidal surfaces}

Velaroidal (velaroid, funicular) [16]) surface is a translation surface with a generatrix curve that changes its curvature in the process of its movement so that the result is the surface on a flat rectangular plane [17]. At present, three types of velaroidal surfaces are known that are parabolic velaroid, sinusoidal velarois, and elliptical velaroid. Sometimes, a velaroidal surface is called a funicular surface. As an example, one can point out the reinforced concrete cover of the Nekrasovskiy (Mal'tsevskiy) market in Saint Petersburg. The middle surface of it is the velaroidal surface on a flat square plan with the dimension of $54 \times 54 \mathrm{~m}$. S.I. Evdokimov, O.B. Golynkin, G.M. Vlanin are the architects and V.A. Il'ina is the engineer. The market was built in autumn of 1960 [4].

Cultural Center in Muscat, Oman, 2011, is the most interesting velaroidal surface (Figure 8,c) of last time.
In some works, velaroidal surfaces on the circular plane are proposed for using but these surfaces have not yet found a real embodiment [18].

In the old time in Georgia, builders have built stone velaroidal domes [19].

\section{Conclusion}

The study shows that many analytical surfaces of revolution and translation surfaces listed in the encyclopedia [1] are not used in architecture and building. These data suggest that geometricians and mechanical engineers are significantly ahead of the needs of architects and builders, or architects have not yet mastered the entire set of analytical surfaces proposed by geometricians, or architects consider the most analytical surfaces unsuitable for their creative concepts. It was found by I.A. Mamieva [20] for ruled surfaces and by the author for surfaces of revolution and translation surfaces.

With the advent of finite difference energy method, finite element method, and other numerical methods, engineers received a powerful tool for the expanded using of thin-walled large-span domes $[12 ; 14]$ and translation shells made of different materials. One can use the nonlinear physical equations and a large deformation theory of shell. For instance, a review of researches of stress-strain state of shells of revolution with arbitrary form of the meridian can be found in [21] with 79 references. This problem has attracted considerable attention from Z.E. Mazurkiewicz and R.R. Nagorski [22] and A. Zingoni [23].

A great deal of surfaces of revolution exists and is studied in different scientific publications. Tens of surfaces of revolution are presented in an encyclopedia [1]. Such surfaces of revolution as "Lochdiskus", "Jet Surface", "Apple Surface", "Kidney Surface", "Fish Surface", "Limpet Torus", Darwin-de Sitter spheroid, and others are known but used much less and may be found in other original sources, for instance, in the internet site [Parametrische Flächen und Körper, http://www.3d-meier.de/tut3/]. 


\section{References}

1. Krivoshapko S.N., Ivanov V.N. (2015). Encyclopaedia of Analytical Surfaces. Switzerland, Springer International Publishing, 752.

2. Krivoshapko S.N., Mamieva I.A. (2018). Analiticheskie poverhnosti $v$ arhitekture zdaniy, konstruktziy i izdeliy [Analytical surfaces in architecture of buildings, structures, and products]. Moscow: Librocom Publ., 328. (In Russ.)

3. Mamieva I.A., Razin A.D. (2014). Parametrical architecture in Moscow. Architecture and construction of Russia, (6), 25-29. https://elibrary.ru/download/elibrary_ 21614483 18612954.pdf (In Russ.)

4. Mamieva I.A. (2011). O klassifikacii analiticheskih poverhnostej [On classification of analytical surfaces]. International Scientific-and-Practical Conference "Engineering System - 2011', Moscow, 63-65. (In Russ.)

5. Krasic S. (2012). Geometrijske Površi u Arhitekturi. Gradevinsko-arhitektonski Fakultet, Univerzitet u Nišu, 238.

6. Krivoshapko S.N. (2019). Optimal shells of revolution and main optimizations. Structural Mechanics of Engineering Constructions and Buildings, 15(3), 201-209. http:// dx.doi.org/ 10.22363/1815-5235-2019-15-3-201-209

7. Mamieva I.A., Razin A.D. (2017). Landmark spatial structures in the form of conic surfaces. Industrial and Civil Engineering, (10), 5-11. (In Russ.)

8. Krivoshapko S.N. (2002). Static, vibration, and buckling analyses and applications to one-sheet hyperboloidal shells of revolution. Applied Mechanics Reviews, 55(3), 241-270.

9. Maan Jawad H. (2004). Design of Plate \& Shell Structures. ASME Press, 476.

10. Lewis M., Ove Arup. (1973). Roof cladding of the Sydney Opera. House Journal and Proceedings of the Royal Society of New South Wales, 106(1-2), 18-32.

11. Brecher K. (2013). Mathematics, Art and Science of the Pseudosphere. Proceedings of Bridges 2013: Mathematics, Music, Art, Architecture, Culture, 469-472.

12. Krivoshapko S.N., Ivanov V.N. (2018). Pseudospherical shells in building industry. Building and Reconstruction, 2(76), 32-40.
13. Krivoshapko S.N. (2017). On application of parabolic shells of revolution in civil engineering in 2000-2017. Structural Mechanics of Engineering Constructions and Buildings, (4), 4-14. http://dx.doi.org/10.22363/1815-5235-20174-4-14

14. Krivoshapko S.N., Ivanov V.N. (2018). Catenoidal shells. Industrial and Civil Engineering, (12), 7-13.

15. Horta-Rangel J., Uehara-Guerrero H., Lopez-Lara T., Perez-Rea L., Hernandez-Zaragoza J. and Rojas-Gonzalez E. (2014). Optimal design of a fabric shell using a coupled femoptimization procedure. Asian Journal of Science and Technology, 5(11), 722-726.

16. Rippmann M. (2016, February). Funicular Shell Design: geometric approaches to form finding and fabrication of discrete funicular structures. (Doctoral Thesis, ETH Zürich). 308. doi: 10.3929/ethz-a-010656780

17. Rippmann M., Block Ph. (2013). Funicular shell design exploration. ACADIA 13: Adaptive Architecture: Proceedings of the $33^{\text {rd }}$ Annual Conference of the Association for Computer Aided Design in Architecture (ACADIA), Cambridge, 24-26 October, 337-346.

18. Krivoshapko S.N., Gil-oulbe M. (2013). Geometry and Strength of a Shell of Velaroidal Type on Annulus Plan with Two Families of Sinusoids. International Journal of Soft Computing and Engineering (IJSCE), 3(3), 71-73.

19. Gogoberidze Ya.A. (1950). Covers "Darbazi". Tbilisi: Tehnika da shroma Publ., 278.

20. Mamieva I.A. (2019). Influence of the geometrical researches of ruled surfaces on design of unique structures. Structural Mechanics of Engineering Constructions and Buildings, 15(4), 299-307.

21. Mihailov B.K., Guriyanov K.V. (1983). Stress state of shells of revolution (reviews of works devoted to linear theory of shells of revolution during the last 10 years). Leningrad: LISI, 28.

22. Mazurkiewicz Z.E., Nagorski R.R. (1990). Shells of revolution. Amsterdam, Elsevier Science Publishers, 640.

23. Zingoni Alphose. (2017). Shell Structures in Civil and Mechanical Engineering: Theory and Analysis. $2^{\text {nd }}$ ed. Thomas Telford Limited, 438.

НАУЧНАЯ СТАТЬЯ

\title{
Влияние геометрических исследований поверхностей вращения и поверхностей переноса на создание уникальных сооружений
}

\author{
Ж.Л. Гбагуиди Айссе \\ Университет Абомей-Калави, 02 ВР 244 Котону, Республика Бенин \\ gbaguidi.gerard@yahoo.fr
}

\section{История статьи:}

Поступила в редакцию: 12 апреля 2019 г. Доработана: 14 июля 2019 г.

Принята к публикации: 22 июля 2019 г.

\section{Аннотаиия}

Цели. Применение, проектирование и расчет архитектурно-строительных конструкций в форме гладких и составных поверхностей стали актуальными и востребованными в последнее время, что обусловило цель данной статьи проанализировать применение аналитических поверхностей, за данных векторными, параметрическими или явными уравнениями, в реальных конструкциях. Методы. Определяется связь между исследованиями по геометрии поверхностей вращения и переноса и созданием новых форм тонкостенных 


\section{Для изитирования}

Gbaguidi Aisse G.L. Influence of the geometrical researches of surfaces of revolution and translation surfaces on design of unique structures (Влияние геометрических исследований поверхностей вращения и поверхностей переноса на создание уникальных сооружений) // Строительная механика инженерных конструкций и сооружений. 2019. T. 15. № 4. C. 308-314. http://dx.doi.org/ $10.22363 / 1815-5235-2019-15-4-308-314$ сооружений и зданий. По каждой поверхности приведен пример реального сооружения. В статье не рассматриваются составные, многогранные, фрактальные поверхности, а также поверхности, не задаваемые аналитически. Результаmbl. Выяснилось, что в мире нашли применение только небольшое число рассматриваемых поверхностей этих двух классов. В конце статьи приведена библиография, в которой изложены математическая сторона проектирования аналитических поверхностей, их компьютерное моделирование, более подробные сведения о реальных сооружениях в форме рассматриваемых поверхностей.

Ключевые слова: поверхность вращения; поверхность переноса; архитектурные композиции; геометрия поверхностей; формообразование поверхностей; классификация поверхностей; тонкостенный купол; оболочка

\section{Список литературы}

1. Krivoshapko S.N., Ivanov V.N. Encyclopaedia of Analytical Surfaces. Switzerland: Springer International Publishing, 2015. $752 \mathrm{p}$.

2. Кривошапко С.Н., Мамиева И.А. Аналитические поверхности в архитектуре зданий, конструкций и изделий: монография. М.: Либроком, 2012. 328 с.

3. Мамиева И.А., Разин А.Д. Параметрическая архитектура в Москве // Архитектура и строительство России. 2014. № 6. С. 24-29. https://elibrary.ru/ download/elibrary_21614483_18612954.pdf

4. Мамиева И.А. О классификации аналитических поверхностей // Инженерные системы - 2011: тезисы докладов Международной научно-практической конференции. М., 2011. С. 63-65.

5. Krasic S. Geometrijske Površi u Arhitekturi. Gradevinsko-arhitektonski fakultet Univerzitet u Nišu, 2012. 238 p.

6. Krivoshapko S.N. Optimal shells of revolution and main optimizations // Строительная механика инженерных конструкций и сооружений. 2019. Т. 15. № 3. С. 201-209. http://dx.doi.org/ 10.22363/1815-5235-2019-15-3-201-209

7. Мамиева И.А., Разин А.Д. Знаковые пространственные сооружения в форме конических поверхностей // Промышленное и гражданское строительство. 2017. № 10. C. 5-11.

8. Krivoshapko S.N. Static, vibration, and buckling analyses and applications to one-sheet hyperboloidal shells of revolution // Applied Mechanics Reviews. 2002. Vol. 55. No. 3. Pp. 241-270.

9. Maan Jawad H. Design of Plate \& Shell Structures. ASME Press, 2004. 476 p.

10. Lewis M., Ove Arup. Roof cladding of the Sydney Opera // House Journal and Proceedings of the Royal Society of New South Wales. 1973. Vol. 106. No. 1-2. Pp. 18-32.

11. Brecher $K$. Mathematics, Art and Science of the Pseudosphere // Proceedings of Bridges 2013: Mathematics, Music, Art, Architecture, Culture. 2013. Pp. 469-472.

12. Кривошапко С.Н., Иванов В.Н. Псевдосферические оболочки в строительной индустрии // Строительство и реконструкция. 2018. № 2 (76). С. 32-40.
13. Кривошапко С.Н. К вопросу о применении параболических оболочек вращения в строительстве в 2000-2017 годах // Строительная механика инженерных конструкций и сооружений. 2017. № 4. С. 4-14. http://dx.doi.org/10.22363/1815-5235-2017-4-4-14

14. Кривошапко С.Н., Иванов В.Н. Катеноидные оболочки // Промышленное и гражданское строительство. 2018. № 12. С. 7-13.

15. Horta-Rangel J., Uehara-Guerrero H., Lopez-Lara T., Perez-Rea L., Hernandez-Zaragoza J., Rojas-Gonzalez E. Optimal design of a fabric shell using a coupled fem-optimization procedure // Asian Journal of Science and Technology. 2014. 5(11). Pp. 722-726.

16. Rippmann M. Funicular Shell Design: Geometric approaches to form finding and fabrication of discrete funicular structures. (Doctoral Thesis, ETH Zürich). 352 p. doi: 10.3929/ethz-a-010656780

17. Rippmann M., Block P. Funicular shell design exploration // ACADIA 13: Adaptive Architecture: Proceedings of the $33^{\text {rd }}$ Annual Conference of the Association for Computer Aided Design in Architecture (ACADIA), Cambridge, 24-26 October 2013. Pp. 337-346.

18. Krivoshapko S.N., Gil-oulbe M. Geometry and Strength of a Shell of Velaroidal Type on Annulus Plan with Two Families of Sinusoids // International Journal of Soft Computing and Engineering (IJSCE). 2013. Vol. 3. Issue 3. Pp. 71-73.

19. Gogoberidze Ya.A. Covers "Darbazi”. Tbilisi: Tehnika da shroma, 1950. $278 \mathrm{p}$.

20. Mamieva I.A. Influence of the geometrical researches of ruled surfaces on design of unique structures // Строительная механика инженерных конструкций и сооружений. 2019. Т. 15. № 4. С. 299-307.

21. Михайлов Б.К., Гурьянов К.В. Напряженное состояние оболочек вращения (обзор работ по линейной теории оболочек вращения за последние 10 лет). Л.: ЛИСИ, 1983. 28 с.

22. Mazurkiewicz Z.E., Nagorski R.R. Shells of Revolution. Amsterdam: Elsevier Science Publishers, 1990. 640 p.

23. Zingoni Alphose. Shell Structures in Civil and Mechanical Engineering: Theory and Analysis. $2^{\text {nd }}$ ed. Thomas Telford Limited, 2017. 438 p. (ICE Virtual Library). 